\title{
HIGH SCHOOL STUDENTS' ATTITUDES TOWARDS THE USE OF A SYNONYM AND ANTONYM DICTIONARY IN LEARNING VOCABULARY
}

\author{
Phung Thi Hang ${ }^{*}$, Nguyen Trong $\mathrm{Du}^{2}$ \\ ${ }^{1}$ Hiep Hoa number 2 High School \\ ${ }^{2}$ TNU - Center of Testing and Quality Management in Education
}

\begin{tabular}{|c|c|c|}
\hline \multicolumn{2}{|c|}{ ARTICLE INFO } & ABSTRACT \\
\hline Received: & $14 / 9 / 2021$ & This paper presents some major findings of a recent research study \\
\hline Revised: & 29/10/2021 & $\begin{array}{l}\text { conducted in a high school in Bac Giang province. One of the objectives } \\
\text { of the study is to scrutinize the students' attitudes towards the use of a }\end{array}$ \\
\hline Published: & $29 / 10 / 2021$ & synonym and antonym dictionary for learning vocabulary. In order to \\
\hline & & achieve this objective, the researchers used action research as the \\
\hline \multicolumn{2}{|l|}{ KEYWORDS } & methodology of the study. The cycle of the research consists of four \\
\hline \multicolumn{2}{|l|}{ Synonym } & action. Questionnaires and interviews were utilized as the research \\
\hline \multicolumn{2}{|l|}{ Antonym } & instruments of data collection. The data collected and generated from \\
\hline \multicolumn{2}{|l|}{ Learn } & these two instruments were analyzed, computerized and synthesized both \\
\hline \multicolumn{2}{|l|}{ Vocabulary } & qualitatively and quantitatively. The results show that, most students \\
\hline \multirow{2}{*}{\multicolumn{2}{|c|}{ Attitude }} & expose positive attitudes, high appreciation and good behavior to the use \\
\hline & & $\begin{array}{l}\text { of the synonym and antonym dictionary to learn vocabulary, and are } \\
\text { willing to introduce this technique to others in their school and in other } \\
\text { schools. From these initial positive results, the researchers suggest that } \\
\text { high school teachers should use synonym and antonym dictionaries more } \\
\text { often in their teaching English, especially teaching vocabulary. }\end{array}$ \\
\hline
\end{tabular}

\section{THÁI Độ CỦA HỌC SINH TRUNG HỌC PHỔ THÔNG ĐỐI VỚI VIỆC SỬ DỤNG TỬ ĐIỂN ĐỒNG TRÁI NGHĨA CHO VIẸC HỌC TỬ VỰNG}

Phùng Thị Hằng ${ }^{1^{*}}$, Nguyễn Trọng $\mathrm{Du}^{2}$

${ }^{1}$ Trưòng THPT Hiệp Hòa số 2-Bắc Giang

${ }^{2}$ Trung tâm Khảo thí và Quản lý chất luợng giáo dục - ĐH Thái Nguyên

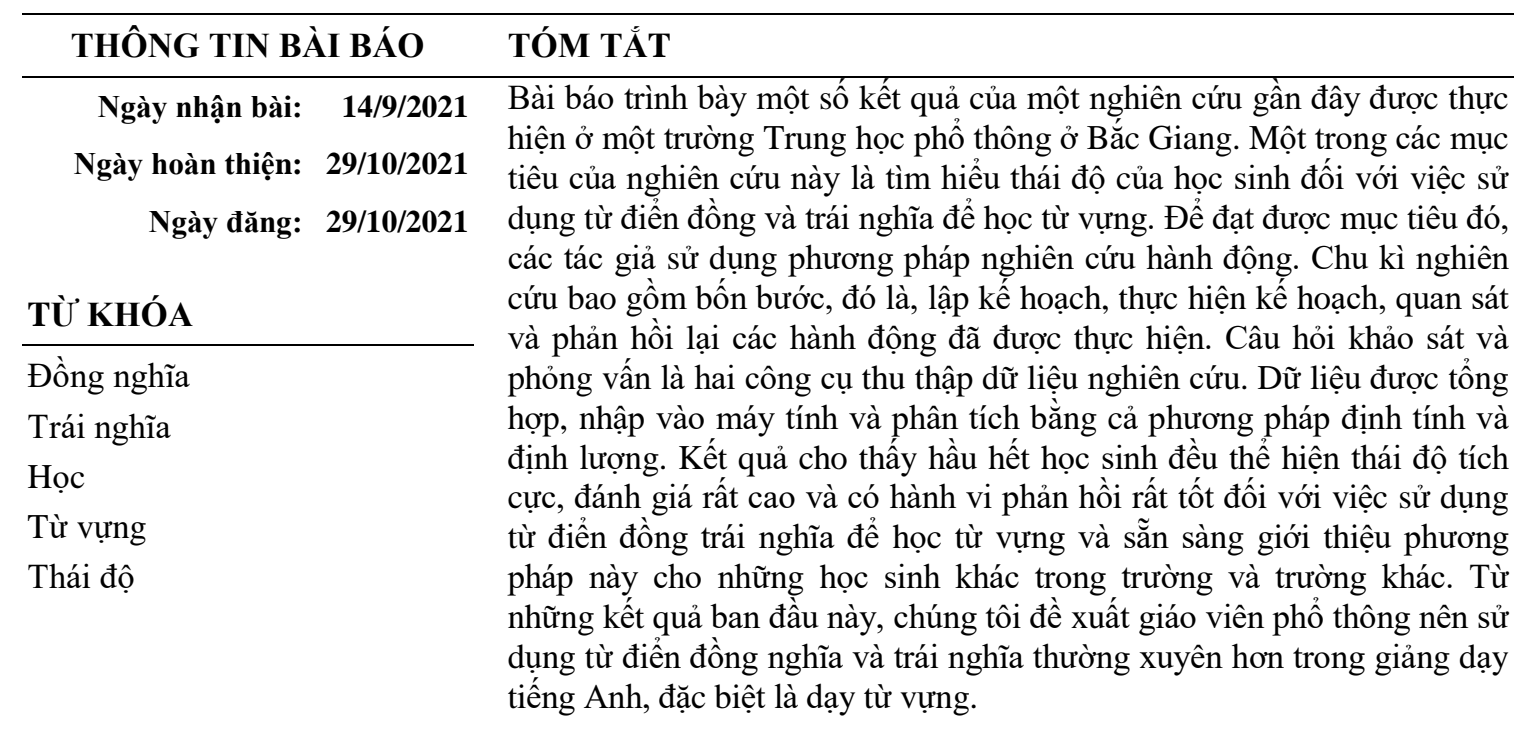

DOI: $\underline{\text { https://doi.org/10.34238/tnu-jst.5034 }}$

\footnotetext{
* Corresponding author. Email: luuhang189@gmail.com
} 


\section{Introduction}

In the current general school curriculum, English is a compulsory subject in almost all high schools in Vietnam, and learners are expected to be able to develop all the four communicative skills, namely listening, speaking, reading and writing. High school English teachers, therefore, need to bear this expectation in mind in order to achieve the objectives of the school curriculum especially the new one issued in 2018. According to Thompson \& Wyatt (1952) (cited in [1]), the teacher should remember the four specific aims while teaching English to students, and they should deal with this issue in the way that during the teaching and learning process, students should be supported and guided to achieve those language skills.

Hynes \& Bhatia (1996) (cited in [2]) also states that English language skills, or proficiency, are key factors for employment success and advancement. In fact, communication skills in English have been identified as indispensable workplace tools for success in business. Thus, in order to achieve a good command of English, students should learn and acquire a good stock of vocabulary that can help them in the development of their language skills. They should be mindful of various techniques or strategies for learning vocabulary. Moreover, the importance of vocabulary in teaching and learning English has been recognized by a good number of researchers such as Carter and McCarthy [3], Nation [4], Huckin et al [5], Schmitt [6] and Alqahtani [7]. They all affirm that vocabulary is the core component in any language syllabus.

To help students widen their vocabulary, teachers of English should see teaching vocabulary as of great importance and should try to find effective methods to teach new words. One of the good methods of teaching vocabulary that has been found in literature is the application of dictionaries. There have been a number of studies on the use of dictionaries in teaching vocabulary and all of them have shown the effectiveness of this method. For example, Mokhtar [8] drew a conclusion that a dictionary was so helpful for learners when it was used as a tool to facilitate their unknown vocabulary. Another researcher, Shen [9], showed that the dictionary, especially an electronic one, improved the students' score on vocabulary size, specific vocabulary and reading comprehension.

In the same vein, Murnani and Salehi [10] implemented a study on the "Impact of using an electronic dictionary on vocabulary learning and retention of Iranian EFL learners". The researchers found out that using an electronic dictionary could help Iranian lower-intermediate EFL learners both have long-term retention of the vocabulary and find unfamiliar words. In a similar study on the use of electronic dictionary, Sri Yanti [11] concluded that the use of electronic dictionary could improve students' vocabulary mastery.

English, a main foreign language, is one of the obligatory subjects in most high schools and in the final exams after students finish their high school. In the context of high schools in Vietnam, English is chiefly taught to support students in the exams, especially the final one to get the General Certificate of Secondary Education (or Chứng chỉ Giáo dục Trung học phổ thông in Vietnamese mentioned in page 45 in English 12 Textbook) and to enter university. However, by observation, the researchers found out that the English command of most students is restricted. In fact, high school students have an enormous difficulty in learning English especially in vocabulary. As a matter of fact, most students are lack of vocabulary and can only use words or phrases given in textbooks. As a result, when encountering synonyms or antonyms of those words in extra exercises or exams, students seemed to be unable to tackle with them. According to Decarrico [12, p. 285], vocabulary acquisition is central to language acquisition, whether the language is first, second, or foreign. Moreover, if learners lack vocabulary knowledge, they soon discover that their ability to comprehend or express themselves clearly is limited [12], [13]. Therefore, in order to help to broaden students' vocabulary and get a basic and deep vocabulary foundation from grade 10, we conducted the study with the topic of using synonym and antonym dictionary to broaden students' vocabulary at a high school. The study aimed at finding out the 
effectiveness of as well as students' attitudes towards the use of synonym and antonym dictionaries in teaching and learning English. However, for the scope of this paper, we just want to present the aspect of learners' attitudes, one of the core factors affecting the success of learning a foreign language. Therefore, the research question tackling this aim is "what are students' attitudes towards using a synonym and antonym dictionary?"

In carrying out this study, we expected that applying this new technique effectively into the teaching and learning process would motivate the learners' positive attitudes in order to achieve higher and more satisfactory outcomes.

\section{Methods}

Action research was used as the methodology of this study. Action research was defined by Kemmis and McTaggart [14, p. 5] as follows: "Action research is a form of collective, selfreflective inquiry that participants in social situations undertake to improve: (1) the rationality and justice of their own social or educational practices; (2) the participants' understanding of these practices and the situations in which they carry out these practices. Groups of participants can be teachers, students, parents, workplace colleagues, social activists or any other community members - that is, any group with a shared concern and the motivation and will to address their shared concern. The approach is action research only when it is collaborative and achieved through the critically examined action of individual group members."

In this study, the action research was implemented to tackle the predicament in broadening vocabulary for 46 tenth grade students at Hiep Hoa number 2 High School using a synonym and antonym dictionary.

\subsection{Procedures}

In this study, the model developed by Kemmis and McTaggart [14] was engaged. The spiral system in this model includes different cycles, but how many cycles an action researcher conducts depends on the effectiveness of the action and also on the researcher' availability of time and effort. For the scope of this study, the researchers conducted only one cycle in the spiral system which consists of four steps namely: Planning, Action, Observation and Reflection. The cycle lasted from unit 7 to unit 10 in English 10 Piloting Textbook.

\section{Step 1: Planning (week 1)}

Before implementing the application of a synonym and antonym dictionary, the researchers conducted a survey with questions in Vietnamese about the state of teaching and learning vocabulary. Through this survey, the researchers got to know the state of students' learning vocabulary which could help the researchers get a proper direction to do the research. Then, the researchers suggested using a synonym and antonym dictionary to broaden students' vocabulary. Next, the researchers made lesson plans for each unit from 7 to 10.

\section{Step 2: Implementing the action (from week 2 to week 12)}

In this step, the researchers implemented the action in the class. The researchers conducted the teaching and learning activities using a synonym and antonym dictionary to look up new vocabulary based on the topic of the current lesson. When implementing the action, the researchers did some activities including asking students to prepare vocabulary (focusing on synonyms and antonyms) before each lesson, presenting the content, giving tasks and giving evaluations.

\section{Asking students to prepare vocabulary before each lesson}

English 10 Piloting Textbook published by Vietnam Education Publishing House was used for the action. In the curriculum, students have three English periods per week, each of which lasts 
45 minutes. The students were taught the words relating to the content of unit 7 , unit 8 , unit 9 and unit 10 in the textbook. In each unit, there were 8 lessons for communicative skills: getting started, language, reading, speaking, listening, writing, communication and culture and looking back and project. Vocabulary was taught in parallel with the skills in each lesson. The researchers asked students to prepare the vocabulary of the new lesson at home by looking for as many synonyms and antonyms as possible using Collin thesaurus Dictionary [15].

\section{Presenting the content in each lesson}

In class, the students were asked to write the vocabulary on the board. Then the whole class along with the teacher would check and complement extra synonyms and antonyms if necessary.

\section{Giving tasks}

The students were also required to do some exercises to check their vocabulary memorization namely matching, speaking the word aloud in English or Vietnamese, and writing all pairs of synonyms and antonyms on the board or in their paper. Besides, each student in the class had to speak one pair of synonyms and antonyms or the students found synonyms and antonyms in word search exercises and the kahoot application.

\section{Evaluation}

The researchers usually examined students' memorization of vocabulary by marking their writing or speaking all the pairs of synonyms and antonyms learned in the previous lesson, or checking exercises in the word search and the kahoot application.

\section{Step 3: Observation (during the study)}

The researchers observed the teaching and learning process by using a recording camera. Thanks to a recording camera, after each lesson, the researchers noted what happened in the classroom down a field note. The researchers watched and analyzed what happened in those periods in field notes. Especially, the researchers recorded students' presentations to know their opinions, comments, questions and behaviors.

Step 4: Reflection (week 6 and week 12)

The information collected from the steps of Evaluation and Observation helped the researchers to have some initial justification of whether the application of synonym and antonym dictionaries was effective and interesting enough or not. Basing on this, the researchers may have to make some adjustment to the lesson plans so that the teaching and learning vocabulary could be better.

All these 4 steps are the general procedures of a normal teaching action that a teacher should follow when s/he applies a new technique or method of teaching. That is why the data collected from the evaluation and observation steps were not used for analysis in this study. In order to answer the research question set out before conducting the study, we used other methods to collect data for analysis, namely questionnaires and interviews, which will be presented hereinafter.

\subsection{Data collection instruments}

\subsubsection{Questionnaires}

Questionnaires [16] were used as a basic instrument as well as a data collection instrument which helped the researchers explore the students' attitudes towards the use of a synonym and antonym dictionary.

The five-point Likert-Scale [17] - [19] was chosen and delivered to 46 tenth grade students. In responding to the questionnaires, the participants were asked to show their extent of attitudes to 
which they agreed or disagreed with the statements by ticking one of the five responses: "1" = "strongly agree", "2" = "agree", " $3 "=$ "no idea", " $4 "$ = "disagree", "5" = "strongly disagree". The options "agree" and "strongly agree" represent the positive response while "disagree" and "strongly disagree" express the negative responses. In order to ensure the reliability of the questionnaires, all items in the questionnaires were both in English and Vietnamese so that students have fully intensive understanding in both languages and complete them easily. In addition, learners were given as much time as they needed to complete the questionnaires.

\subsubsection{Interviews}

Apart from the quantitative data collected from questionnaires, interviews [20] were conducted with 10 students to collect qualitative data. The purpose of interviews was to get information directly from the students about themselves, teaching situations, their attitudes or opinions on some issues and their suggestions on what should be done by the researchers when conducting the research. Accordingly, the researchers interviewed the students about their viewpoints toward using a synonym and antonym dictionary. Individual semi-structure interviews were applied in this study to encourage learners to express their ideas freely within a given framework. The learners could express what they thought while the researchers could collect immediate evidences.

\subsection{Data Analysis}

The researchers collected both qualitative and quantitative data. All the data were analyzed to meet the requirements of the study.

The questionnaires were delivered to determine the students' attitudes towards using the synonym and antonym dictionary to learn vocabulary. Data from the questionnaires were sorted out. The same opinions were counted and converted to the percentage and then demonstrated in the tables and charts. Comparing the percentage of the agreement opinions and the disagreement ones, the researchers found out the treatment.

To get more feedbacks from the students when applying using the synonym and antonym dictionary in teaching and learning vocabulary, the researcher interviewed the students who had different opinions about this technique. The responses were transcribed, translated into English and presented by citing relevant ideas. Then they were described, analyzed and synthesized.

In summary, the data reflecting the students' attitudes were collected from feedbacks from the questionnaires and interviews, which were demonstrated and analyzed to gain the research findings.

\section{Results and discussions}

\subsection{Results from the questionnaires}

The research questions are created and self-edited by the researchers based on the purpose of the research and the actual goals that students need to achieve. One of the two parts of questionnaires aimed to explore the learners' attitudes towards the technique of using the synonym and antonym dictionary in learning vocabulary after the intervention. The learners were required to reply to seven statements number $1,2,9,10,11,15$ and 16. To make the comparison easier, the researcher grouped "strongly agree and agree" as one category and "disagree and strongly disagree" as one category. The responses and the results of the statistical analysis were presented in detail in Table 1.

As can be illustrated in Table 1, all students thought that broadening vocabulary is very important and the synonym and antonym dictionary is very convenient for learning vocabulary. Most students approved that the synonym and antonym dictionary could provide vocabulary's meanings exactly and nearly all of them found vocabulary in the synonym and antonym dictionary reliable and useful. Only one student (2.2\%) disagreed that the synonym and 
antonym dictionary provided vocabulary's meanings exactly because he found it difficult to understand words' meanings in all contexts. Moreover, $100 \%$ of the students wanted to continue using the synonym and antonym dictionary to learn vocabulary. After all, most students $(96.5 \%)$ desired to introduce the technique of using synonym and antonym dictionary to learn vocabulary to their friends.

Table 1. The attitudes of the students towards the synonym and antonym dictionary for learning vocabulary

\begin{tabular}{|c|c|c|c|c|c|c|c|c|c|c|c|}
\hline \multirow[t]{2}{*}{ Statements } & \multicolumn{2}{|c|}{$\begin{array}{l}(1) \\
\text { Strongly } \\
\text { agree }\end{array}$} & \multicolumn{2}{|c|}{$\begin{array}{c}\text { (2) } \\
\text { Agree }\end{array}$} & \multicolumn{2}{|c|}{$\begin{array}{c}(3) \\
\text { No idea }\end{array}$} & \multicolumn{2}{|c|}{$\begin{array}{c}(4) \\
\text { Disagree }\end{array}$} & \multicolumn{2}{|c|}{$\begin{array}{c}\text { (5) } \\
\text { Strongly } \\
\text { disagree }\end{array}$} & \multirow[t]{2}{*}{$\begin{array}{c}\text { Total } \\
\text { (strongly } \\
\text { agree }+ \\
\text { agree) } \\
\end{array}$} \\
\hline & 莺 & 를 & 窇 & 苞 & 冚 & 苞 & 异 & 吾 & 莺 & 疍 & \\
\hline 1. I think broadening vocabulary is very important. & 37 & 80.4 & 9 & 19.6 & 0 & 0.0 & 0 & 0.0 & 0 & 0.0 & 100 \\
\hline $\begin{array}{l}\text { 2. I think the synonym and antonym dictionary is } \\
\text { very convenient for learning vocabulary. }\end{array}$ & 18 & 39.2 & 28 & 60.8 & 0 & 0.0 & 0 & 0.0 & 0 & 0.0 & 100 \\
\hline $\begin{array}{l}\text { 9. I think the synonym and antonym dictionary } \\
\text { provides vocabulary's meanings exactly. }\end{array}$ & 15 & 32.6 & 27 & 58.7 & 3 & 6.5 & 1 & 2.2 & 0 & 0.0 & 91.3 \\
\hline $\begin{array}{l}\text { 10. I find vocabulary in the synonym and } \\
\text { antonym reliable. }\end{array}$ & 15 & 32.6 & 29 & 63.0 & 2 & 4.3 & 0 & 0.0 & 0 & 0.0 & 95.6 \\
\hline $\begin{array}{l}\text { 11. I find vocabulary in the synonym and } \\
\text { antonym useful. }\end{array}$ & 13 & 28.3 & 33 & 71.7 & 0 & 0.0 & 0 & 0.0 & 0 & 0.0 & 100 \\
\hline $\begin{array}{l}\text { 15. I will continue using the synonym and } \\
\text { antonym dictionary to learn vocabulary. }\end{array}$ & 11 & 23.9 & 35 & 76.1 & 0 & 0.0 & 0 & 0.0 & 0 & 0.0 & 100 \\
\hline $\begin{array}{l}\text { 16. I will introduce the technique of using } \\
\text { synonym and antonym dictionary to learn } \\
\text { vocabulary to my friends. }\end{array}$ & 17 & 37.8 & 27 & 58.7 & 1 & 2.2 & 0 & 0.0 & 0 & 0.0 & 96.5 \\
\hline
\end{tabular}

In conclusion, most of the students expressed positive attitudes, high appreciation and good behaviors towards using the synonym and antonym dictionary in vocabulary learning. This technique created a good impression on the participants. They found it exciting and effective in their vocabulary learning. They were confident to make a personal synonym and antonym dictionary. They were also willing to use the synonym and antonym dictionary regularly and would introduce this technique to others in their school and in other schools.

\subsection{Results from the interviews}

When the students were asked what they liked best when using the synonym and antonym dictionary technique for learning vocabulary, they were willing to give their responses freely. One student said that she could gain both vocabulary and grammar in the synonym and antonym dictionary. A schoolboy shared that the synonym and antonym dictionary was convenient and useful for her vocabulary learning. A schoolgirl gave more opinions that the synonym and antonym dictionary helped her save time because it had double knowledge. In fact, she could learn many different words from one original word. Three other students shared the idea that they could get a large number of words because when they knew one word they would know several synonyms and antonyms and it was the combinations of synonyms and antonyms that helped them remember and master more vocabulary. A quite active student reported that the thing she liked best when using the synonym and antonym dictionary was that she knew more new words and could apply them in vocabulary exercises and communication more smartly.

The question "What don't you like best when using the synonym and antonym dictionary technique for learning vocabulary?" centered on the weak points of the synonym and antonym dictionary. Only three out of ten students showed their answers. They stated that it was difficult 
for them to guess meanings of words in different communicative situations in high-level exercises. In fact, one word has many different meanings and has some different synonyms and antonyms used in various situations. As a result, they sometimes mistook one meaning for another one if they did not understand the communicative situation.

All students gave the responses to the differences between using the synonym and antonym dictionary technique and other vocabulary learning techniques and their preference. Most students shared some common opinions. The students stated that vocabulary of the new lesson was often provided by their teacher. Then they learned by heart and wrote them on the board in the following lesson. That way they felt free to get high marks. However, they found it difficult to remember words in a long time. Therefore, they only knew words given by their teacher without mastering a variety of relating words. After they had been instructed the way to learn vocabulary using the synonym and antonym dictionary, they collected more benefits. They could learn more words systematically. A schoolboy added that they could remember words faster and longer and became more active in looking up words and remembering pairs of synonyms and antonyms. Accordingly, they could also make a word list on different topics at any time. Interestingly, the students affirmed that they had enriched their vocabulary from words given in a textbook thanks to a synonym and antonym dictionary. In general, all of ten students interviewed approved that this technique took more advantages over others.

With the question "Do you think you will continue to use the synonym and antonym dictionary technique? Why?/ Why not?", $80 \%$ of the interviewed students would like to use the synonym and antonym dictionary technique in the future because of its practical benefits and desired to recommend this technique to others. Only two students refused to use it. Both of them thought it took them much time to look up synonyms and antonyms and they wanted to concentrate on their favourite scientific subjects. They could only remember synonyms and antonyms provided by their classmates through the synonym and antonym dictionary.

In conclusion, most students believed that this technique was good and useful in learning vocabulary and desired to keep using it in the future.

\section{Conclusions}

After applying the use of a synonym and antonym dictionary, the students tended to spend more time on synonyms and antonyms by looking up and learning them more actively. They expressed great interest as well as attraction to learning synonyms and antonyms.

With the data collected, completed and analyzed, the study provided several essential findings. One of the findings is that the students had great excitement and motivation with new atmosphere in class to be engaged to vocabulary learning. They felt not only active in looking up and learning synonyms and antonyms but also confident to make their own synonym and antonym handdictionary. They also found learning vocabulary through synonym and antonym dictionary so effective. They were interested in vocabulary activities the teacher introduced which helped them get a larger amount of vocabulary than ever before. They wanted to look for and collect more and more vocabulary related to the chain of words in the textbook. They reported that they felt happy when they could self-study and look up and remember more and more vocabulary after each lesson. As a result, they had positive attitudes towards vocabulary learning.

Through the data collected from the interviews, the learners revealed positive attitudes, punctual perception and good behaviors towards using synonym and antonym dictionary technique by giving its advantages. Using synonym and antonym dictionary technique was very useful in helping the students learn, remember and broaden their vocabulary. It also helped the learners have a good awareness of learning vocabulary. Therefore, the students got an effective method of vocabulary learning.

This study brought out some practical implications for both the teachers and students. For the teachers, the findings of the current study could be applied for language teachers in classroom to 
facilitate vocabulary teaching and learning. Thanks to positive effects of synonym and antonym dictionary technique, it should be encouraged to be employed not only in class but also during the students' self-study time in order to improve their vocabulary. Moreover, teachers need to create more activities to encourage learners to use synonym and antonym dictionary to revise the vocabulary they learned and broaden their vocabulary. For the learners, synonym and antonym dictionary technique should be used more frequently in vocabulary learning to broaden as well as reinforce their vocabulary. It should be employed in the classroom in order to create abundant learning styles for the students. Applying this technique to other students, the teachers will make the learners more active in their vocabulary learning.

To sum up, the result of the significant findings in the data collected from the questionnaires and interviews presented the advantages of using the synonym and antonym dictionary technique over the existing methods of teaching and learning vocabulary at Hiep Hoa number 2 High School. There were strong evidences supporting the benefits of using synonym and antonym dictionary technique in broadening the students' vocabulary at this school. The results were also consistent with the literature review and previous studies on vocabulary. It was believed and hoped that this technique might be suitable for most students at this school as well. It can also be stated that the present study, to some extent, helped the researchers tackle the learners' problems in vocabulary learning. Therefore, further studies on the use of a synonym and antonym dictionary should be carried out with other participants on a larger scale and if possible in different contexts.

\section{REFERENCES}

[1] D. R. Manjula, "Teaching English language: principles and practices," Journal of Emerging Technologies and Innovative Research, vol. 5, no. 6, pp.384 - 386, 2018.

[2] V. S. Durga, "The Need of English Language Skills for Employment Opportunities," Journal for Research Scholars and Professionals of English Language Teaching, vol. 2, no. 7, pp.1-5, 2018.

[3] R. Carter and M. J. McCarthy, The General Service List (GSL), Chapter 1, Michael West, 1988.

[4] I. S. P. Nation, Teaching and Learning Vocabulary, New York: Newbury House Publishing, 1990, pp. $1-275$.

[5] T. Huckin, M. Haynes, and J. Coady, "Second language reading and vocabulary learning," Norwood NJ: Ablex Publishing, 1993, pp. 1-309.

[6] N. Schmitt, "Vocabulary: Description, Acquisition and Pedagogy," in Vocabulary Learning Strategies, Cambridge: Cambridge University Press, 1997, pp. 199-227.

[7] M. Alqahtani, "The importance of vocabulary in language learning and how to be taught," International Journal of Teaching and Education, vol. 3, no. 3, pp. 21-31, 2015, doi: 10.20472/TE.2015.3.3.002.

[8] A. A. Mokhtar, R. M. Rawian and M. F. Yahaya, "Vocabulary Knowledge of Adult ESL Learners," English Language Teaching, vol.3, no.1, pp. 71-78, March 2010.

[9] Z. Shen, "The Effects of Vocabulary Knowledge and Dictionary Use on EFL Reading Performance," English Language Teaching, vol. 6, no. 6, pp.77-84, 2013.

[10] Z. T. Murnani and H. Salehi, "Impact of using an electronic dictionary on vocabulary learning and retention of Iranian EFL learners," International Journal of English Language and Literature Studies, vol. 5, no.1, pp. 55-65, 2016.

[11] S. Yanti, "Improving students' vocabulary mastery through electronic dictionary," Indonesian EFL Journal, vol. 2, no. 2, pp. 88-99, 2016.

[12] J. S. Decarrico, "Teaching English as a Second or Foreign Language," in Vocabulary Learning and Teaching, M. Celce-Murcia Ed., London, Thomson Learning, 2001, p.285.

[13] I. S. P. Nation, Learning vocabulary in another language, Cambridge: Cambridge University Press, 2001.

[14] S. Kemmis and R. McTaggart, The Action Research Planner, 3rd ed., Deakin University Press, Geelong, Victoria, 1988.

[15] Collin Theasaurus Dictionary. [Online]. Available: https://www.collinsdictionary.com/dictionary/ english-thesaurus. [Accessed June $10^{\text {th }}, 2021$ ]. 
[16] C. E. Hilton, "The importance of pretesting questionnaires: a field research example of cognitive pretesting the Exercise referral Quality of Life Scale (ER-QLS)," International Journal of Social Research Methodology, vol.10, pp. 1-14, 2015. [Online]. Available: https://www.researchgate.net/ publication/282796273_The_importance_of_pretesting_questionnaires_a_field_research_example_of_co gnitive_pretesting_the_Exercise_referral_Quality_of_Life_Scale_ER-QLS [Accessed June 12 ${ }^{\text {th }}, 2021$ ].

[17] S. Jamieson, "Likert scales: how to (ab) use them," Medical Education, vol. 38, no. 12, pp. 12171218, 2004.

[18] S. A. McLeod, "Likert Scale". [Online]. Available: https://www.simplypsychology.org/likertscale.html [Accessed June $15^{\text {th }}, 2021$ ].

[19] R. Likert, "A Technique for the Measurement of Attitudes," Archives of Psychology, vol. 140, pp. 1$55,1932$.

[20] E. Adhabi and C. B. Anozie, "Literature Review for the Type of Interview in Qualitative Research," International Journal of Education, vol.9, no.3, pp. 86-95, 2017. 